\title{
The Approach of the Social-Political Problems, in the Comedies of Kristo Floqi
}

\author{
Dr. Jonela Spaho \\ Faculty of Education and Philology \\ "Fan S. Noli" University, Korçë, Albania \\ Email: jspaho@gmail.com
}

\section{Doi:10.5901/mjss.2014.v5n1p467}

\begin{abstract}
Kristo Floqi is not only one of the most popular authors of Albanian comedy of the period 1912-1939, but can rightly be considered the founder of this genre, developed later in Albanian literature. As comedy arises as a need of expression in a society that seeks to emancipate because it mocks vices and shortcomings of the society, Kristo Floqi the 1912-1927 time frame, sharpened the pen of satire and humor and wrote about 20 comedies and farces which appeared on the scene from amateur theaters that existed at the time in Albania. One of the main goals of his comedies was the treatment of political and social issues of the time. He lived in a chaotic political reality that was present in Albania after the Declaration of Independence he found himself, being in power and closely to people the problems facing the state and society of that time and reflected on them with realism in his comedies. Social and political issues of his comedies mocked using power, ignorance and parasitism in power, intrigue, loss of national sentiment, greed for power, etc. Also, his comic pen has even treated some moral wound of the reality, such as hypocrisy, fraud, greed for wealth etc. The fact that the public received with pleasure and interest these comedies, and even applauded the strong ones, shows that these played their part comedy "catharsis" for the Albanian society, during the period after the declaration of Albanian Independence.
\end{abstract}

Keywords: idiomatic, satire, grotesque, catharsis, reception

\section{Introduction}

Kristo Floqi is a multifaceted personality, whose work evokes curiosity and harassing any interested researcher, especially, for the period of the first half of the twentieth century. His role as an active man in Albanian culture and thought must be appreciated, especially in the context of the time as a deliverer quantitative and qualitative deliverer of the dramatic, whose work was widely liked and received time audience, especially his comedy through genre which he became the most prolific author and the most popular period. He is among the most prolific authors of Albanian comedy for years but lacked the blend in the history of Albanian literature and has been excluded from any critical assessment literary and historical, illiteral because of his political life. Kristo Floqi, fed on the rich resources of Greek literature, fitted after university studies in Athens, with the American Western culture in recent years of the 19th century and early 20 the century, has had all subjective and objective conditions to give something really qualitative in the development process of the Albanian literature, especially drama. Robert Elsie qualifies him as the most popular Albanian playwright in the first half of the 20th century, (Elsie Robert, 1997, page 356) and Gaetano Petrotta, as an Albanian writer, who has provided name in the future. (Pettrota Gaetano, 1932, page 299).

As the need arises, the comedy of expression in a society seeks to emancipate. The release of comedy, like the kind of dramatic sex is an expression of emancipation and social development, the strengthening of critical consciousness of a society that aims to integrate the modern processes of its life. It is known that the development of comedy, especially its critical character, withering negative phenomena of society can exist when there are grounds for a certain freedom of critical thought. Aristotle in his work "Poetics" writes that comedy is imitating everything worse from what it is in reality and mimics those attachments that are funny. According to him, if tragedy is intended to reflect the people better than they actually are, comedy reflects people not only across forms, but also in the form of their ridiculous. (Aristotle, 2004, page 20).

Kristo Floqi took precisely this need, not only of Albanian literature, but the free expression of opinion on a number of phenomena that disturbed the society of the time when he lived, to the sharpened pen of satire and humor, giving us a range of works in the comic genre. Thus in the period 1912 - 1927, he wrote a considerable number of comedies as: "Brotherhood and interest" (1920), "Minister Candidate" (1921), "Opponents of dowry" (1922), "The Banker's Daughter" (1922), "Groom in rape" (1922), "Take it to receive"(1922), "Black on Black" (1923), "Salaries of employees" (1923), 
"Akraballëqet" (1925), "The province's granddaughter "(1926), "Advertising bluff "(1926), "Doktorings" (1927), etc.

As noted by researcher Jakup Mato, K. Floqi, has the ability to detect comedic occurrences in life and knows the experience of prominent satirists, but without forgetting the sting, the ironies and even satirize the vices of negative phenomena.(Mato Jakup, 1996, page 373-376).

According to studies conducted over the years the theater of $1912-1939$, in Albania, the researchers noted that in this theater striking predominance of comedies and especially comedies of Kristo Flogi and that for some priorities oft this kind of dramatic genre. In fact comedy is described as a compensation philosophy as much as psychological. Whenever we become aware that this world is not the best possible, we need the comedians help to cope with "loopholes" of the insurmountable reality. High comic vision of life is humor; it's a human achievement as a human being. Meredith had this in mind when he said that comedy is our ultimate civilizer. In all civilized societies soul must stand up comic ally with laughter, thin tense and alert for any society is no healthy without laughing at itself (Meredith George, 1956, page 47).

It is known that since its beginnings, comedy has been a valuable mechanism of essential pleasure for the audience and the society in which he lived. So, Kristo Floqi's comedy, receipted so widely from the audience of time, there was definitely a fun but a liberation of different energy, and regret and reflection on characters and characters that make us laugh at the stupidity of vices and mistakes, but we find it difficult to accept ourselves as their carrier. However reflective effects and "catharsis", present an opportunity to explain the potent broad audience in Flogi's comedies when they were written. The evolution of comedy to us in the first half of the 20-th century, relates inevitably with the conditions and requirements of Albanian society and this can better ascertained of studying these comedies.

\section{Political and Social Issues}

The time when Kristo Floqi created most of his comedy and farce, and coincided with important political - social changes. Situated at the top and the government itself, as Minister of Education in the cabinet of lljaz Vrioni, in 1920, a member of Dibra and then Korca, Chairman of the High Council of State, he took an active part in these changes. Apparently, he wrote most of his comedies in Albania when changes were sensitively taking place in the social and political matters. It is not easy to sting and satirize political cliques and characters, when you are part of them. At the time he wrote comedies that address in important political issues - social policy and lampooned evil, and he himself was in charge of the government, is not accurate to claim that he was drawn by the government, to further dealt with light exposing the vices of moral hypocrisy, deceit, greed for profit, false advertising, etc. It is exactly the time when switching sequentially some short-term government, which did not have the opportunity to disclose the place of the chaos that existed, even, in some cases, it increased it further. Chaos clearly reflected the political and social life, in ways of patriarchal life mindsets and mentalities. Thus, the subject of his humor and satire became a series of regressive kinds of persons who started from the pyramid of power to the ordinary people of Albanian cities, mainly Tirana and Korça, who often are the main carriers of deformation of moral vices. The period 1920-1927 was characterized by a series of events. The situation appeared rather more difficult. New governmental programs were not clear and were turned back down. The large number of employees in the administration was paradoxical for a country like Albania while the cost of living had increased greatly. In Highlands riots began before the laws were drafted and were very strict. lliaz Vrioni, generated in these conditions, was forced to resign and the task of forming the new cabinet was assigned Pandeli Vangjeli. But the creation of the new government, the crisis in the country was more sore to avoid the consequences and Pandeli Vangjeli resigned, and so a new government was formed under the leadership of Hasan Prishtina, but like the first it had a short life, because after five days resigned and a new government was established, under the direction of Shefqet Vërlaci. After this period we have the June Revolution, and the collapse of its coming into force of Ahmet Zogu, who appears on the political scene as Prime Minister and as the King of Albanians until 1939, the year when Albania was occupied by fascist Italy. Having lived and worked in these conditions, many important political issues of the social time, were the subject to treatment in his comedies. Taking a closer look behind the scenes problems and failure of some governments, he sharpened pen harsh satire and humor and in 1922 wrote the operetta in 4 acts "Political gourd". The title of the work suggests the idea of what it will be treated and scourged. The density of the events and consequences of the policy period not functional in this operetta was reflected in all their complexities. Seen in this light, this work is characterized by deep treatment of political and social issues. Operetta, not coincidentally starts with discussion of some deputies, who are concerned by the loss of their sofa. Rhyming names of the ridiculous characters created better ideas of these types, who as the only salvation for their post saw the establishment of a Constituent Assembly. Speaking about lljaz Vrioni interim government, which dissolved the parliament and promulgated a new law on elections of deputies. It is this new law that concerns characters 
deputies, who have decided to protest. To implement this decision of the Government and organizers come from Afghanistan. At this point begins the sharp humor and satire, which finds occasion to appear in the words of the characters and the closing track of the organizers choir, in which they make a generalization and a sarcastic comparison of the state of Albania with third world country of Afghanistan. The dialogue of the deputies with the organizers is one of the most beautiful parts of comedy, because it creates the mood and situation comedy hit. Other scenes bring Operetta overtaking a number of personages, who come from different spheres of social life Albanian creating the comic scenes, the dramatic and at the same time.

Through all this gallery of personages forming a characters comic masquerade the author tries to sting once with easy humor irony of driving time with the sarcasms call satire, bad policy, which is taking the country in a dead end. Being a thin watcher of phenomena, problems, and different types of phenomena, of the Albanian society, it seems that his pen has not escaped any aspect. In this way, the operetta is conceived as a mosaic revealing the Albanian politics, bringing in new characters in every scene, which converse with each - other by prominent negative phenomena and draw conclusions in the closing chorus songs.

In the scenes that follow, the author touches on a number of problems related to the area of employment, the Albanian education system, with the damaged infrastructure, misused, finances, corrupted judicial system, the administration personnel with unqualified people etc. Although these problems are vital for the normal functioning of the state, whose real situation arouse fear and uncertainty about the future of the country, the author is credited to detect in them the comical side. Kristo Floqi, being a competent expert on these problems, runs until the end of observation and disclosure of phenomena although they sound painful, especially for the fact that the consequences of ordinary people suffer. The author, through the exquisite irony, satire and sarcasm that often goes to the grotesque, and condemning the main responsible of this situation, gives suggestions to get out of it and sometimes the language used at work and take our advice. Only a thin and attentive observer and a master in the use of tools such as "Political Gourd", because he does not stop only in exposing the negative phenomena, but also regressive types of the Albanian society. He satirizes intense thirst for power, bribery, organized backstage to possess a government position etc.

It seems that these people suffer the consequences of simple and honest, who returned only remained at the phenomena but have no power to stop them, to remain passive and waiting: "Our politicians has blinded thirst for power and can put their house on fire. Once the wood will find mules but how much money does"(Flogi Kristo, 1922, page.74). Author of particular concern in the state administration and the Albanian state overloaded with incapable and corrupt people, who have not taken place in its ability but grubby dealings friendships, while the wise and honest, simple patriots are unemployed and hopeless.

The situation is worrying, especially in the judicial system, which appears in all its nakedness, the appeals for the judges to organize the improperness for lawyers that practiced their profession without diplomas relevant to customers who extort, trials that lose etc. At the end of the work, the author has not unintentionally set a very important aspect that creates the image of the Albanian state in the world and that has to do with the appointment of Albanian diplomats. Sharp satire here takes bold grotesque forms, when it comes to appointments to diplomatic posts of unfit people who are representative of a typical environment of a backward mentality of oriental their inability to demonstrate through words and actions. Particularly pronounced notes of humor and satire in the scene given that, when revealed through their iconic contrast of their damaged professional portrait, instead of wondering about serious policy and practice to represent their country with dignity in the world, while contemplating which cook will take away, dresses, receptions and entertainment.

But it seems that the author's final slogan is not completely pessimistic. In this reality to confuse many problems with corrupt politicians and incompetent officials, he will find value and therefore calls on everyone to "drop down to earth": "Often new line, in the breastfeeding of people has many good boys and men that could certainly lead Albania to face every danger if not felt woefully ignored these man! - says an organizer. (Ibid, page, 96)

The same themes and problems are in addressed in the comedy of "Salaries of employees", the events of which already have been displaced from Albania, in the offices of the Ministry of Foreign Affairs of Italy. Comedy opens with a dialogue between civil justice, Halldupit and a finance officer, Dudumi, who worked in the administration of the Government of Prince Wilhelm Wied. It is this dialogue, which reveals the true nature and character of these people without any moral value, which by assuming that the Albanian government has gone to overthrow the government of Prince Wilhelm Wied, demanding that their salaries be back and paid by the Italian government. Their dialogue with a loaded language of Turkish, the unmasking of these grotesque characters that do not have anything to sell their land in return for material benefits. Dudumi is a character from the comic characters in the most prominent negative of all of his comedies. His grotesque appearance carries ideaemotional writer and attitude. As a denier of his country, and he is also 
the holder of all vices. The comical part of this character is that he is aware of his immoral actions. In this comedy, the author proceeds by way of introduction, at any stage of a character, creating in each one of these anti - portrait, once again through satire and grotesque. Much of the comedy's moments were realized when these employees presented again, but this time before continuing, Italian officials highlight other aspects of their character. Here humor and satire create a situation as comical and tragic. Kristo Floqi, as a psychologist of thin social consciousness of that time, especially of some types, whose features has increased by grotesque, sees a serious threat to the future of the country. Satire becomes sharper when former Minister Plenipotentiary of Albania, which has brought any value and has lost his personality, put in the same position with these thugs and ignorant and requests the salary paid to him by the Italian government. At the end of the comedy, his harsh tone softened and the award of counsel and a moral message, a message of hope and awareness: "You thought that Albania died, but you are wrong, so that a nation cannot miss "and finally"':" "The more you keep the patriots the more you appreciate the honor of your self (Floqi Kristo, 1923, page 50).

Issues affecting the areas of political and social life and treated in the Albanian comedy "Minister Candidate" events which take place in Tirana in 1921. It is time the government has just been overthrown and the Coalition formed a new government under the leadership of Pandeli Vangjeli, a government in which the main character of the comedy dreams and desires to take a position. In this comedy, the edge of irony and satire to reach grotesque, aims to strike the phenomenon of thirst for power of some stupid and ignorant types who have no ideal of the utmost couch and advantages it brings.

Barkaleci (the tummy fat man) appears as a realized character whose comism lies in the contrast between ignorance and his desire to be appointed minister at any cost. For this reason it is not only the object of ridicule by his colleagues, but also by his servant, who does not hesitate to make fun of them ironizing in any case. The comic node begins precisely with the presentation of his servant Barkalecit and place the scene in the scene where the character is fully revealed Minister Candidate who is ready to sacrifice his family and for the sake of power. The author through this kind, seeks to satirize all those pseudo who lives and raise their goals on the power dreams, without any ideal in the middle, the guys with their inability to realistically assess things, do remember that the homeland service taking these positions, but in fact, with their stamp shameful day on history.

This fact is Highlighted beautifully scene when he dreams of favors that will provide office and has casually longed for them to complain great burden that has taken over: "The heavy burden that is upon us, but when Thenceforth you do not have a homeland charges. If Homeland is good anyway"( Flogi Kristo, Tirana, 1926, page 36). The comedy ends with a reflection on the character of all that happened. In fact, the end sounds a bit unmotivated considering how he sought earnestly and without logic on undeserved place in power, but apparently the author is trying to adapt the comic nature of the criminal end.

Political problems, coupled with social and comedy have "Akraballëket"(Turkish word implies favoring somebody in properly) events which take place in Tirana in 1925. Comedy focus on important issues related to political and social reality of the country in the period when the events take place, such as use of power, corruption, etc. In the center of the comedy is set to name a deputy significant Pivot, around which all the other characters revolve, who want to benefit from his undeserved favors on behalf of a kinship which, in fact is fabricated. Exactly how to try to create these absurd links and based on their personal problems lay, related to their inability lies in the source of all humor in comedy. But the irony and satire of the work done by the powerful scenes when the characters presented the corrupted and the ignorant, who have lost their jobs due to abuse and require the deputy to intervene to return them to work. Humor and satire stands out strongly when they seek to protect their ideas and do not realize that they have overcome any ethical and moral norm. Thus, a village teacher, who has only two high school classes, wants to be the General Director of Education and the author takes the opportunity to ask important issues relating to the state of education in Bangladesh. Also, the comedy satirizes a corrupted customs officer, an accountant who has abused state money, a conductor roads and so naive. Humor reaches its highest peaks with the absurd demands of Sorollop, and fanaticism with which he protects and the deputy asks them: "therefore opted member", he repeats this phrase as a refrain whenever the deputy opposes it. "This provides us keep the promises that you made when you gave the vote" - he continues becoming more and more ridiculous.

All these affect and disturb the deputy, who often speaks on behalf of the author, especially when he mocks and satirizes these guys. Kettle, his servant, seeing the plight that has occupied the master, concludes that he rather would be a public servant. Exactly, in those moments when it seems that it is exposed and convicted of bribery, comics node is created when a member is bringing several letters from people of his relatives, who appointed official positions, positions which they abused and ask for his protection. Here he loses his temper and leaves all to servant's hand who begins to have fun and make fun by driving away all peoples. Comedy treats a negative phenomenon of time, that carries current 
value.

The problem of abuse of official position, incompetence and corruption, coupled with pleasant humor scenes, raises and comedy "The Province's granddaughter", the center of which is located provincial a remote village, which was occupied by visits panic the inspector that will expose all its abuses. Province accused of embezzling the money given to the development of roads, allowing the smuggling, not convict people who have broken the law, no neutral stance in the municipal elections, as was required by his position, and so on. The author mocks and satirizes the offense and some senior officials of the state administration, by striking ignorance and their alogysm, such as the mayor of Berat, who gave orders that all day to simply stop stuttering employees and sneezing during office hours. In fact, comedy is built with comic situations, which aim to build more comic intrigues and find the solution, rather than punish vice, and abusers. However, the value of comedy is that satirizes the corrupt officials who seek to escape the situation by any means, even deceiving.

A significant problem and raises social comedy "Doctorings", which focuses on the edge of satire as a dangerous phenomenon is the practice of the profession of doctor of profane people without degrees who have the main goal of profit and non- treatment patients. Comedy events held in the home of a wealthy sick Nardini, who sends his servant to bring home doctor, but a servant, being confused by false advertising brings doctor instead of once a pharmacist, a dentist time and time undergraduate lying on tables write "Doctor", he brings veterinarian. This situation reached a climax when the servant brings a doctor instead of a lawyer who, like everyone else seeks compensation for "trouble". Satire to be driving when their servant Nardini and pretends to be a doctor. However he was noted as resourceful smart person when working as a doctor manages to cure the master, whom he knows well and knows which disease he suffers from the gaining back the money he owed to him.

Kristo Floqi's comedies dealing with political issues - social, although few in number and receive a special significance value, putting the finger on the wound occurrence and types of negative phenomena of time and hitting and satirizing them. The range of issues addressed in them is spacious and the pyramid starts from the state goes to the lowest levels of his, giving them artistical strength generalizing, but universal, because the problems addressed in this comedy are evident in every time. Even from the standpoint of performance art these are among the most beautiful comedies, in which the author has skillfully utilized, knowing all stylistic effective means of satire and humor, depending on the topic and in order to address disclosure, sting and shock direct or type of event comic phenomenon, thereby creating the comic of this works.

\section{Social and Moral Issues}

Part of the comedy is the focus Kristo Flogi unveils vices, moral mistakes and weaknesses of the Albanian social life of the time. "Brotherhood and interest": the two extremes together to witness the almost tragic truth, how far human beings can achieve on behalf of financial benefit. Any kind of feeling fades, brotherhood love, love for children, love for man in general. Kristo Flogi through moments in this comedy reveals psychological tendency of people to humble you only interest, a phenomenon that is happening constantly and in modern times taking tragic. Brotherhood and interest actually dates back to the origins of humanity and shows us the modern inhabitants of our planet, that human nature remains essentially the same, often distorted and inhuman. This old motive wearing an old robe in Floqi's modern comedy, where the author has cleverly prominent human psychology and displays a character combining the best and the dramatic point of view. The problem addressed in this comedy takes such universal values. Seen in this light and artistic realization in the plane, with the characters of comic situations, and psychoanalysis sense, this comedy remains one of the best works of Kristo Floqi.

Plenty of accomplished by addressing the problem and created characters and comedy is "Opponents of dowry". Hypocrisy, the antipodes of the truth and the right, appears in this comedy with all its nakedness. Hypocrisy damages social relationships, undermines and distorts human society. This deformation is tragic when it's done through youth, who allegedly speak on behalf of the changing ideals of a patriarchal society where they are part of it. The author through Petraqi's characters, Kostaq and Jorgaq, the anachronistic types of playboy calls show to which human fallacy goes , which is able to destroy and significant values such as friendship, life and love. These three characters who give themselves as moderate, but overloaded of conservatism and prejudice requiring a change in the old habit, that of bringing girls dowry when they marry and become promoters of the removal of a tradition that is outdated because according to them it is the man who has the duty to provide economically for the family. But when the time comes to ask girls for marriage, they are interested in other's, secretly married girls who had the greater dowry. This hypocrisy, full of humor and pleasant scenes that Pantushi reveals, server café they frequented. The author in this comedy touches 
passing and a range of other social problems such as greed for profit, marriages without consent of the youth, deception and lies, prejudice and patriarchal lifestyles.

The moral problem of counterfeiting, fraud and hypocrisy in the name of profit and raises no sweat comedy "Advertising and bluff", which are the focus of two young men from Shkodra; Zef and Kelly. In fact the subject is simple, but the subtext reveals through major significance as failure, fraud, naivety, hypocrisy, which damage society, especially when these habits of young bearers who should take the important mission of transforming its. Two young Shkodra people, play a game of one charging (Zef) the false advertising of property. The message is human comedy, in any decent society or dishonest, or emancipated conservative, patriarchal or modern, fraud can have different faces, but the same end. The author upsets position of these young people who fail to become masters of themselves and change the society in which they live, but through research parasitism and easy ways to make profit providing a range vices that make their character uglier.

The pen of Kristo Floqi have not escaped the important social problems such as those unwillingly marriages, that does not take into account the wishes of the youth. Beautiful handle this problem is comedies "Groom with rape" and "Banker's daughter". The first comedy, whose events take place in Korça, in 1885, addresses the problem in the most comedic potential, but the subtext is clear : love triumphs and defeats any kind of trade, and at the expense of its speculations. In another comedy raise the issue of conflict between generations, the issue of importance that takes money, which eclipses the parental interests, the issue of marriage for the sake of interest, etc. The characters in this comedy of youth, unlike those of the first, are described with sympathy and warm feeling. This shows that the author's attitude is not just withering on youth addictions, but also sympathetic when they stand up to their fate and try to fight against old habits and mentalities. Despite the comedy situations and dialogues are light and humorous, the arises problem remains important especially for the writing.

As mentioned, Kristo Floqi lived in a period when the life and the lifestyle Albanian's lifestyle had significant changes. This change is transmitted even in lives of the Albanian women, who faced transformations, changes of contact with the world that wants them to live in a patriarchal environment, a life that do not respond to the European standards. In Kristo Flogi's comedies, the opposite happens, of what indeed happens to the female's characters of other comedians of the period. Woman's the one that predominates and imposes its will and desires on her husband, until the dispute actually reaches a critical point.

It is in the comedy "Man - Man" is reflected match the old patriarchal time with the new time, which brings with it the spirit and the modern way of living and thinking. Minister Hilmi researcher stresses that this comedy is Kristo Flogi horizon targets local circumstances and moods in Albanian. This is more specifically, the city of Korça environment in the period when he had begun to break through the Parisian fashion. Socially speaking this is when part of the Albanian society, still undefined in social layers begin in earnest, but often artificially, without being consolidated, half come from the state's rural and semi- urban bourgeoisie made at least by dressing "Man - Man" has affected more subtle appearance in this aspect, the Albanian woman wants to rise to a high degree, even defeat and husband , Kristo Flogi's episode takes a host, as he concentrates them at the tip and so creates protagonist characters or holders of an event. Here, specifically, is considering an Albanian woman, wife of an honest officer, whose mind works only for fashion catalogs and economically destroys the family, that is held only by the man's salary: "I wish I had more money, would bring all of Paris here ... Ah Paris, Paris". But through the hit comic situations and understanding thanks to the servant man, arrives to stop the inflated desires of his wife.

Vice of hypocrisy, as one of the greatest defects of man, which disrupts and destroys relationships and rules imposed by society, appears more open than elsewhere and more grotesque elements of the comedy.

"Black to Black", which increases the habit by keeping the black, but while teasing her and bring it to an end. The approach of hypocrisy and conclusions of this problem is secondary as the excess of black inmates, brings a deep breath and emancipation not only in this comedy Kristo Floqi. This emancipator spirit is felt in all his comedies and has not been otherwise with a man who had ideal Albanian prosperity and civilization, which he devoted all life, and sacrificed for. But this spirit of emancipating the author should have strong grounds to be create and developed worthy people to support him.

So he's sympathetic laughter once again biting, mocking and ironic times, sometimes sarcastic and grotesque. Let's not ridicule, especially women characters who seek emancipation crooked ways, mainly by filling their egos and cheated predominantly in the unfair. However, the closure of his comedies creates us a glimmer of hope, which promises for the future. Types that he has outlined in this comedy, which dealt with moral problems, although often given to the grotesque, deformed by vice, have a route change and they finally realize this. All comedies are ultimately moral turned around and often order the author. In this regard, although not often in a logical and compelling way the characters 
change. This underlines the optimistic idea of the author. And this is not otherwise happen with comedy, which without this optimistic conclusion would not ever realize "catharsis our" spiritual because, as we said, we laugh at the comedy habit, fear our suspicions, but we find and defense the mechanism that allows us to reach to the "salvation" and the final emancipation. This was well understood and Kristo Floqi, his comedies to this topic no doubt perform their function in the emancipation of the Albanian society civilized time when he lived.

\section{Conclusions}

However, various scholars have argued that Kristo Floqi'scomedies, and in particular some of those that affect important social problems, have met great void that has existed in our comedic-graphic in this period and for several reasons.

He is the first author of the most prolific period in the field of comedy, and his work was widely receipted audience through the staging of amateur bodies. Kristo Floqi also gave a series of attractive forms of building intrigue comic contradiction, has conducted several prominent characters, has structured attractive entities and has enriched our literature with a set of expressive means comics. (Mato Jakup, 1996, page 375).

We often find moments of psychological universal values in his works, which makes his current works even today, as a part of the characters that are not related only to the circumstances and the Albanian environment but can be adapted to any environment, any people, any time and any place. In his comedies, Kristo has outlined his mentality of Korça and Tirana and we can say that it is some kind of chronicles of the social phenomena of everyday life of Tirana, Korça, addressing various social performances. In this treatment of events, on the one hand, it saves the environment from Oriental physiognomy and local petit bourgeois psychology of the character, while on the other side he tries to put in the form of modern social life, and the dynamic pace of the experienced days.

Kristo Floqi had the merit of creating texture comedies in the functional structures that highlight the ridiculous side of life. Given these important aspects mentioned, his work deserves attention and a deeper study of comics, especially to note positive trends and the quality of his work and in the context of the overall development of our comedy in first half of the 20 - the century.

\section{References}

Aristoteli, (2004) Poetika, Tiranë.

Bergson Henry, (1956) Laughter, New York.

Cuddon J. A, (1988) A dictionary of literary terms, New York.

Elsie Robert, (1997) Historia e letërsisë shqiptare, Tiranë-Pejë.

Floqi Kristo, (1926) Akraballëket, Tiranë.

Floqi Kristo, (1943) Burri-burrë!, Tiranë.

Floqi Kristo, (1969) Komedi të zgjedhura, Prishtinë.

Floqi Kristo, (1926) Ministri kanditat, Tiranë.

Floqi Kristo, (1922) Qerthulli politik, Tiranë.

Floqi Kristo, (1923) Rrogat e nëpunësve, Tiranë.

Mato Jakup, (2000) Paradokset e satirës dhe humorit, Tiranë.

Mato Jakup, (1996) Rreth disa komedive të Kristo Floqit, Letërsia si e tillë, Tiranë.

Meredith George, (1956) Essay on comedy, New-York.

Petrota Gaetano, (1931) Popolo lingua e letteratura albaneze, Palermo. f. 249

Qosja Rexhep, (2000) Historia e letërsisë shqipe, Romantizmi, III, Tiranë.

Sypher W., (1956) (Ed.), Comedy, New -York.

Uçi Alfred, (2001) Estetika e groteskut I, Tiranë.

Uçi Alfred, (2001) Grotesku në letërsinë shqipe, Tiranë.

Xhiku Ali, (2004) Letërsia shpipe si polifoni, Tiranë.

Historia e letërsisë shqiptare, (1933) Tiranë.

Shkrimtarë shqiptarë II, (1941) Tiranë.

Studime dhe kritikë letrare nga autorë të Kosovës, Maqedonisë e Malit të Zi, (1983) Tiranë. 
